involving the use of plastics were discussed and the advantages of the use of colour photography.

Dr. F. B. Hora gave the presidential address to the Botanical Section, his subject being "Toadstools". He dealt with two aspects of his subject: descriptive, dealing with classification, morphology, anatomy and ecology; experimental with cytogenetics, pure physiology and nutrition. He welcomed the opportunity of giving an address which gave a far wider scope than his usual lecturing, which confines him to factual information. Mentioning that there were still those who considered there should be three kingdoms of living things-vegetable, fungi and animal-he spoke of the revolution in classification during the past thirty years, largely brought about by the microscopic examination of spores and also by the ecological approach - the relation of living things to one another and to their environment. Many people regarded all toadstools as poisonous, but of the total number in Great Britain-approximately 1,600 - only three were deadly, eight were serious, while a further thirty should be avoided. Thirty were well worth trying, and half a dozen, in addition to the mushroom, were really good to eat. Dealing with the experimental side of his subject, he spoke of the counts of selected species on continuously limed plots in woodland, of the restriction of some species to burnt areas and of observations on selected acid and alkaline natural soils. Dr. Hora concluded by stressing the importance of work by amateurs conducting simple experiments and the collation of their results.

Prof. H. L. Hawkins addressed the Geological Section upon "The Geology of Reading with reference to the Kingsclere Excursion". He commenced by outlining the movement of the Earth's crust during the Carboniferous period. There was a northward surge; rock waves moved several miles until they reached masses which would not move and upon which they smashed like waves on a beach. Dry land and desert dunes persisted after the uplift until the sea encroached from the south and east and drowned the ground; during this period the Jurassic rocks were formed. The Cretaceous sea next invaded the land; during the long Chalk time there was nothing but sea in the area, and a thickness of $1,300 \mathrm{ft}$. of microscopic life was deposited. The water drained off, leaving a level surface; but, by gravity, the weight soon crushed the softer deposits, causing different levels on the surface. The sea again encroached from the south and east and the Eocene Beds were deposited, although for part of that time in the Reading district the water was either fresh or brackish. Prof. Hawkins traced the later geological history to the point of the formation of a valley of elevation on the top of the syncline at Kingsclere. When the sea receded from the region of the British Isles, denudation, including glaciation and solifluxion, formed the Kingsclere valley with an Upper Greensand mound at the centre, indicating the position of the rock masses which caused the original Carboniferous bulge.

Dr. C. C. Balch chose as the subject for his presidential address to the Zoological Section "The Birds of Reading". He said that to enjoy bird-watching it was necessary to know something of birds, their rarity and their behaviour. The present tendency is, perhaps, to concentrate on sewage farms and gravel pits, this distracting from the importance of general observation in the area. Within a five-mile radius of Reading there were 210 species recorded, and detailed observation of their occurrence and habitats were essential to a balanced survey. The gravel pits provided very good records of oceanic types: all three divers were present ; eighteen species of duck, twenty-two waders, and both aretic and common tern were present in numbers. Among the numerous rare species mentioned by Dr. Balch was the recording of wrynecks breeding in two districts within the circle.

The full programme of Congress excursions was successfully carried out. The archæologists visited the Roman city, Calleva Atrebatum, at Silchester, the ancient parish church and the priory at Pamber. The botanists went to Silchester Common and Pamber Forest; the zoologists to Aldermaston gravel pits for observation of ducks, waders and early summer migrants. The geologists made a complete traverse of the western part of the London Basin to Kingsclere and, on the return journey, studied the features of the dissected gravel plateau that formerly covered the entire district. General excursions were conducted to the abbey ruins and gateway and to Messrs. Sutton and Sons' seed trial grounds, where special attention was given to the Grass Advisory and Vegetable Plant Breeding Stations.

Mrs. W. Fishlock, the local honorary secretary, was responsible for the excellent arrangements, and the help of the University authorities in providing lecture theatres and accommodation was greatly appreciated.

The sixty-fourth Annual Congress will be held next year during Whitsuntide at Salisbury in conjunction with the South-Western Union.

F. J. EPPS

\title{
THE CARNEGIE UNITED KINGDOM TRUST
}

\section{REPORT FOR 1957}

$\mathrm{T}$ HE forty-fourth annual report of the Carnegie United Kingdom Trust* covers the year 1957, the second of the present quinquennium, and records no change either in the policy of the Trust or in that of the Government in response to pressure for State aid for the non-national museums. An encouraging response to the offer of grant-aid to pre-war halls in small villages for the improvement of furniture and

* Carnegie United Kingdom Trust. Forty-Fourth Annual Report, 1957.) Pp. ix +59. (Dunfermilne : Carnegie United Kingdom Trust, equipment is reported. The Trust has undertaken to support the development of advice services in rural areas and has begun to take an active interest in the social problems of new towns and housing estates. Its main new policy in the field of education is one providing financial assistance to amateur scientists participating in group activities, and bursaries enabling them to attend field-study centres were awarded to forty-five students who were members of twentyseven societies. Besides $£ 1,750$ for such bursaries, these grants, totalling $£ 1,000$, are offered for amateur 


\section{№. 4625 June 21,1958}

field work in archæology through the Council for British Archæology, and $£ 2,000$ has been earmarked for the preparation of a directory of local scientific societies, for which the British Association has accepted responsibility (see Nature, 181, 741 ; 1958). Other grants in the field of education include $£ 4,000$ over five years to the Scottish Women's Rural Institutes towards a programme of one-day and three-day schools and courses in various centres, at first on such subjects as public speaking, procedure at meetings, duties of office-bearers, etc. A similar grant over four years has been made to the York Academic Trust to establish in the Institute of Architectural Study, York, a national reference centre on the protection and repair of historic buildings, which will contain bibliographies, technical drawings, photographs, leaflets, exhibits and models on every aspect of the subject and will be equipped to deal with research, correspondence and personal inquiries. A major experiment which terminates in 1958 is the one-year course in applied social studies at the London School of Economics, but the course has so well justified itself that it has already been decided. to give training in generic case-work a regular place in the School's curriculum of professional training for social workers. Generic case-work courses have also been started in the Universities of Southampton and Birmingham.

Provision in aid of museums absorbed $£ 11,804$ of

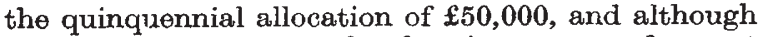
only $£ 328$ of this was for fees in respect of expert reports on twenty-seven museums, the benefits conferred appear far to outweigh the cost involved. Grants totalling $£ 8,560$ were offered in 1957 to seventeen museums to enable them to execute plans for re-organizing their collections and for improving the display of their material, and a grant of $£ 1,500$ was made to Trinity College, Dublin, to defray the cost of reorganizing the display of the "Book of Kells" as a centrepiece in the Long Room of the Library, with other exhibits suitably disposed. For pre-war village halls serving rural communities of not more than 1,000 people, the Trust has set aside $£ 100,000$ for re-equipment, and expenditure in 1957 amounted to $£ 3,233$. Nine applications for film projectors for crofting communities served by the Highlands and Islands Film Guild were approved during the year, and $£ 5,000$ to be disbursed over five years has been allotted in support of an effort by the National Council of Social Service and by rural community councils to strengthen the citizens' advice bureaux already run by the councils, to estab. lish bureaux in small country towns and link these with the countryside, and to encourage experiments. A sum of $\$ 5,500$ over two years has been allotted for training six people each year for full-time community centre wardenship. Financial interest in family service units in 1957 was limited to training social workers in such techniques, and to research in which good progress was made with inquiries into problems of families with handicapped children. $£ 3,000$ was granted to the Scottish Epilepsy. Association for its workshop scheme.

\section{THE SMITHSONIAN INSTITUTION}

\section{REPORT FOR 1956-57}

T WE report of the Secretary of the Smithsonian Institution for the year ended June 30, 1957*, to which are appended the financial report of the Executive Committee of the Board of Regents, and reports on the library and on publications and on branches of the Institution, makes special reference to the functions of the Institution as a museum. The United States National Museum, the National Collection of Fine Arts, the Freer Gallery of Art, the National Air Museum, the National Zoological Park and the National Gallery of Art all contain public exhibits, and as a group these Smithsonian units care for the great national collections of the United States, constituting one of the largest and most distinguished groups of cultural and scientific collections in the world.

Much progress was made during the year in the work of the United States National Museum, and when the new Museum of History and Technology now being planned is completed it will be one of the world's finest museum buildings. Plans for new wings for the overcrowded Natural History Building were also included in the 1958 appropriation, and the modernization of the public displays of the Institution continued during the year. Some progress is reported in the collections and facilities of the National Zoological Park, which is still inadequately housed. The calendar year 1956 marked a peak in

- Smithsonian Institution. Report of the Secretary and Financial Report of the Executive Committee of the Board of Regents for the year ended June 30,1957 . Pp. $x+204+9$ plates. (Smithsonian Publication 4308.) (Washington, D.C.: Government Printing Office,
1958.) the activities of the Biosciences Information Exchange, which, operating within the Smithsonian, acts as a clearing house for current research in the biosciences and now covers 14,000 active research projects.

Accessions to the National Museum during the year totalled 647,750 specimens, and field-work was conducted in Bermuda, Brazil, Canada, Ecuador, Europe, Mexico, Panama, Peru, the Philippines and Society Islands, and many parts of the United States. These included field studies of the flora of southern Brazil, researches on the distribution and variation of the bird-life of the Isthmus of Panama, marine studies at the Bermuda Biological Station, and inquiries by Dr. D. J. Price for suitable nineteenth-century chemical and physical laboratory apparatus to illus. trate the history and principles of these sciences in the displays now being planned for the new exhibit halls as well as regarding early scientific instruments.

The Bureau of American Ethnology's systematic researches during the year included archæological reconnaissance in Ecuador, studies of museum collections in Europe of Mesolithic materials for their possible bearing on the Eskimo problem, and studies of the Florida Seminole and among the Seneca. The River Basins Survey continued its programme for salvage archæology and by the end of the year 350 sites in forty-seven reservoir basins in eighteen States had been excavated, and the Missouri Basin Project alone had eatalogued 749,244 specimens from 1,725 numbered sites and fifty collections not assigned site numbers. The manuscript collections of the Bureau 